\title{
Ease of Phytochemical Extraction and Analysis from Plants?
}

\author{
Aytac KOCABAS \\ Karamanoglu Mehmetbey University, K.O. Science Faculty, Biology, Karaman, Turkey \\ aytackocabas@kmu.edu.tr
}

\section{Bitkilerden Fitokimyasal Özütlemenin ve Analizinin Kolaylı̆̆ı?}

\begin{abstract}
Plants are vital and sustainable resources for our world. From the ancient times, they are not only supplier of oxygen but also the important part of the food pyramid. Besides, they are sources of thousands of bioactive phytochemicals. With emerging technologies, human being can made synthetic drugs based on phytochemicals to improve their life quality. However, nowadays, Humans have started the search again for natural sources because of emerging new diseases and side effects of drugs. Although lots of chemicals identified and purified from plant materials, it is obvious that there is still more phytochemicals than we discovered especially for foods. Determining full potential nutraceutical value of foods may lead classical breeding or biotechnological studies to more promising area. In concordance, aim of this review is to briefly indicate the bottleneck of analysis of plant phytochemicals by pointing the critical parts of the whole analysis process.
\end{abstract}

Key words: Phytochemicals, Phenolics, Extraction, Antioxidant Capacity

Özet: Bitkiler, dünyamız için hayati ve sürdürülebilir kaynaklardır. Eski çağlardan beri sadece oksijen tedarikçisi değil aynı zamanda gıda piramidinin önemli bir parçasıdırlar. Ayrıca, binlerce biyoaktif fitokimyasalın kaynağıdırlar. Gelişmekte olan teknolojilerle, insanoğlu fitokimyasallara dayalı sentetik ilaçlar üretebiliyorlar. Ancak günümüzde insanlar ortaya çıkan yeni hastalıklar ve ilaçların yan etkilerinden dolayı doğal kaynakları araştırmak için tekrar arayışa girdiler. Bitki materyalinden tanımlanan ve arıtılmış birçok kimyasal madde olmasına rağmen, özellikle gıdalar için keşfettiklerimizden çok daha fazla fitokimyasalın bulunduğu açıktır. Gıdaların potansiyel nutrasötik değerinin belirlenmesi, klasik sslah veya biyoteknolojik çalışmaların daha umut verici bir alana gelmesine neden olabilir. Bu amaçla, bu incelemenin amacı, bütün analiz sürecinin kritik kısımlarına işaret ederek bitki fitokimyasal analizinin darboğazını kısaca göstermektir.

Anahtar Kelimeler: Fitokimyasallar, Fenolikler, Özütleme, Antioksidant kapasite

\section{Introduction}

In addition to being one of the main food sources for humans and animals, plants have been used as the main source of treatment for many diseases throughout history (Cheynier, 2012; Oroian and Escriche, 2015; Shahidi and Ambigaipalan, 2015). The metabolites that the plants produce to protect themselves against biotic and abiotic stresses have turned into medicines that people can use to treat various diseases (Bhattacharya et al., 2010; Elmastas et al., 2017; Galindo et al., 2017; Liu et al., 2017). In ancient times, the treatment is carried out by direct usage or brewing of this plant, on the other hand, currently, the active ingredients are purified and synthetically produced with new technologies (Cheynier et al., 2013; Pezeshkpour et al., 2018).

From past to present day, plants used as natural medicines in the treatment of many diseases. Among these diseases, we can give an example of a wide range from simple injuries to stomach aches to feverish diseases to aging (Bahiense et al., 2017; Dai and Mumper, 2010; Ferhat et al., 2017; Kolakul and Sripanidkulchai, 2017; Li et al., 2018; Mabeku et al., 2017; Marques et al., 2017). In the past years, plants were being used directly and the information about how their mechanisms and dosage were decided by means of trial and error. Moreover the information flow from one generation to next is by means of hearsay. However, with today's technology, active substances can now be identified and purified and effects and dosage can be determined individually (Azmir et al., 2013; Barb a et al., 2016; Bhat and Riar, 2017; Dominguez-Rodriguez et al., 2017; Nadpala et al., 2018; Wang and Zhu, 2017).
The importance of dosage of any substances is indicated by "Sola dosis facit venenum " in Latin which means "the dose makes the poison " in English. The phrase is the condensed form of Paracelsus statement "All things are poison and nothing is without poison; only the dose makes a thing not a poison " (Siddiqui et al., 2003; Stall et al., 2008). In addition, in 1907, Paul Ehrlich introduced the chemotherapy concept using Arsphenamine, the first synthetic drug, in medical therapy (Siddiqui et al., 2003). With the concept of chemotherapy, dosing was become widespread around the world. We can illustrate the significance of the dose through vitamin $\mathrm{C}$, which everyone knows very well. Everyone can easily mention the benefits of vitamin $\mathrm{C}$, but the less known part is the reversal of the antioxidant properties, especially when taken at high doses, where it acts like free radicals (Oroian and Escriche, 2015). Similar situations apply to all medicines we actually use. In synthetic drugs, the dose concept is determined by bio-accessibility as measuring the absorption level, the serum value and the excretion of the drug. However, it is not possible to carry out a similar research method to measure the bio-accessibility of direct usage of plants. Firstly, the plant has many bioactive substances. Secondly, the absorption of bioactive substances depends on the material of the plant, the way of use and the interactions of bioactive chemicals. Phytochemicals in the plants can exhibit synergistic effect and increase the effect or show antagonistic interaction and reduce the efficiency (Acosta-Estrada et al., 2014; Burgos-Edwards et al., 2017; Celep et al., 2017). Therefore, the usage of plants and/or their extracts, and the phytochemical combinations should be considered carefully. 
With the added concern of antibiotic multiple drug resistance and the side effects of synthetic drugs, research has turned to finding new and natural resources. The high potential of plants as having bioactive phytochemicals, decrease in the cost and time of the research for finding, and assessing antioxidant substances have been resulted in focusing on finding and determining the phytochemicals in plants and their usage as natural sources.

Antioxidants prevent damage to lipids, proteins and DNA by means of preventing radicals initiation, breaking chain propagation or suppressing formation of them. Thus, they can prevent deteriorating disease (i.e. cancer) and slowing down the aging process (Bahiense et al., 2017; Iseri et.al., 2011; Kada et al., 2017; Nunes et al., 2017; Oke-Altuntas et al., 2017; Pisoschi and Pop, 2015; Sadi and Sadi, 2010). The phytochemicals having antioxidant activity can be grouped in 3: vitamins, carotenoids and phenolics (Oroian and Escriche, 2015).

Plants are used for food and medical treatment from ancient years. Although, thousands of plant bioactive compound have been determined, purified and used as drug substance, there is still need for further investigation to reveal the full potential of plants especially for foods. Therefore, the aim of this paper was to briefly cover the bottleneck of the discovering new chemicals from plants by focusing on phenolics and their extraction methods and analysis procedures.

\section{Phenolics in Plants}

Although the phenolic and polyphenolic terms are used as synonymously, the definition of polyphenolic should be as the phenolics that contains at least 2 phenol rings. The definition of polyphenol was first used in 1962 and was later revised in 1994 and 2011 and accepted as "term polyphenol should be used to define the plant secondary metabolites derived from the shikimate derived phenylpropanoid and/or the polyketide pathway(s), featuring more than one phenolic ring and being devoid of any nitrogen-based functional group in their most basic structural expression" (Cheynier, 2012) (Figure 1).

Although the secondary metabolites are not considered as vital metabolites, they help the organism in its survival. Plants produce many phenolic substances as secondary metabolites. However, the type and amount of phenolic substances varies according to plant material, the biotic and abiotic stresses that the plant is experiencing with regard to the physical and biological interaction of the plant with the soil microorganisms, season, and environment (Demir et al., 2014; Elmastas et al., 2017; Galindo et al., 2017; Majdoub et al., 2017; Martini et al., 2017; Mirto et al., 2018; Ojeda-Amador et al., 2018; Petropoulos et al., 2017; Petropoulos et al., 2018; Silva and Sirasa, 2018; Sutay Kocabas et al., 2015; Tupec et al., 2017). Some phenolic species are common and widespread among plants, while some are species-specific. Because, these substances are the metabolites of plants and their production is related to the metabolic activity, thus, their genetic background (Cheynier, 2012; Cheynier et al., 2013) (Figure 2).

The phenolic substance identified from the plants has exceeded 8000 and increasing in number every day (Cheynier, 2012). Although the extraction and analysis of phenolic substances from plants seems to be very easy, it is not true that they can be obtained by a single process or by a single method. As mentioned, the quantity and type of phenolic substances are influenced by many factors, so it is not possible to obtain them by a single method (Acosta-Estrada et al., 2014; Castro-Lopez et al., 2017; Dominguez-Rodriguez et al., 2017; Pezeshkpour et al., 2018). Similarly, antioxidant capacity assays cannot be assessed through a single method since they can be water soluble or bound to cell materials such as cell membrane. It was also indicated in literature that bound phenolics have higher antioxidant capacity than water soluble ones (AcostaEstrada et al., 2014; Dominguez-Rodriguez et al., 2017; Shahidi and Zhong, 2015). Therefore, both for extraction and analysis at least more than one method or combination of methods should be used to precisely determine phenolics.

\section{Extraction Methods}

Along with the anxiety caused by the side effects of synthetic drugs, recent research has focused on the nutraceutical properties of plants and foods. The most prominent features of these properties are the antioxidant capacities and the most studied and investigated molecules among the antioxidants are phenolic molecules (AcostaEstrada et al., 2014; Cheynier, 2012; Cheynier et al., 2013).

Obtaining a molecule from a plant takes place in five steps: i) macroscopic matrix pretreatment, ii) molecule separation, iii) molecule extraction, iv) purification, and v) product formation (Galanakis, 2012; Oroian and Escriche, 2015). It should be noted that the most important step is the extraction. Because being easy and cheap at this stage, the organic solvent extraction method is the most cited method in the literature. In addition, pulsed electric fields, ultrasound, high pressure processing methods are cited as more technological and effective processes to increase the yield (Azmir et al., 2013; Barba et al., 2016; Castro-Lopez et al., 2017; Dominguez-Rodriguez et al., 2017; Pezeshkpour et al., 2018). Therefore, it will be the best to select the combination of methods and process depending on the plant material and desired molecules.

\subsection{Organic Solvent Extraction}

The organic solvent extraction phase uses either a single solvent (water, ethanol, ethyl acetate and hexane) as solidliquid extraction or an aqueous form of these solvents as a two phase extraction method. In general, ethanol is preferred because at the point of consumption of the molecules obtained, ethanol is considered as "Generally Accepted As Safe (GRAS)" according to American Food and Drug Administration (Azmir et al., 2013; Nunes et al., 2017; Oroian and Escriche, 2015). On the other hand, the studies showed that addition of water to the extraction solvent resulted in increase in the yield of phenolic compound extraction. Moreover, it should be indicated here that for carotenoid extraction, acetone or ethyl acetate had higher yield than ethanol (Oroian and Escriche, 2015). Furthermore, acid addition to organic solvent is recommended for anthocyanin extraction. Another important point for extraction is extraction time and temperature. Especially for longer time, the yield decreases because of the oxidation of the phenolics (Dai and Mumper, 2010). Therefore, although aqueous ethanol extraction is widely used and accepted method, it is wise to consider that the interaction between solute and solvent system determines the solubility. Besides conventional 
solvent extraction, special extraction methods can be performed.

\section{Super Critical Fluid extraction}

Super critical fluid extraction is the usage of the fluid at their super critical stage. Accepted as GRAS, $\mathrm{CO}_{2}$ was the generally used fluid in this method. Although it requires a special equipment, it is fast process and requires less amount of sample, and solvent than conventional solvent extraction (Azmir et al., 2013; Castro-Lopez et al., 2017; Dominguez-Rodriguez et al., 2017).

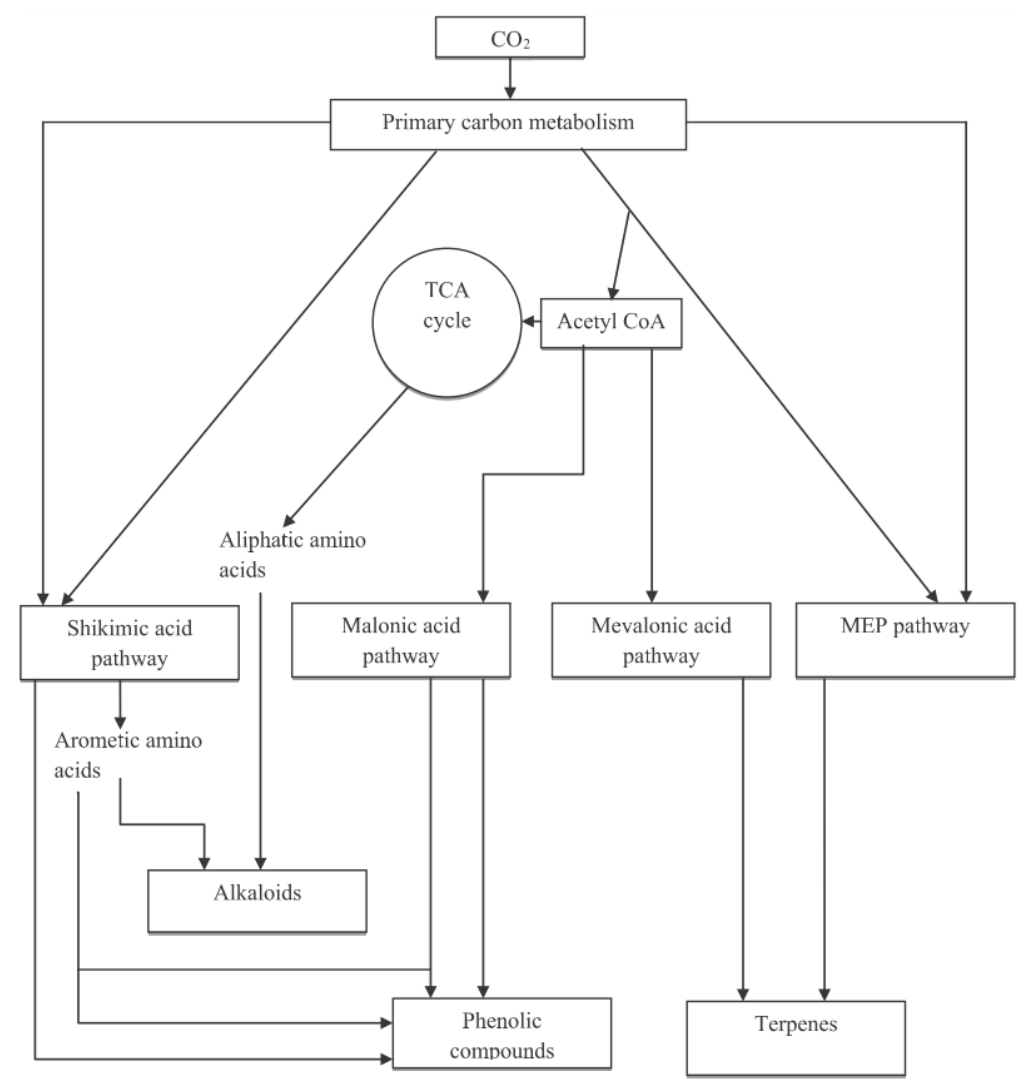

Figure 1. Pathways for production of three major groups of plant bioactive compounds (Azmir et al., 2013).

\section{Subcritical water extraction}

It is performed by keeping water in its liquid form at higher degrees of temperature such as $100-300{ }^{\circ} \mathrm{C}$ by controlling pressure. Therefore, this process reduces water polarity and provides the solubilization of both hydrophobic and hydrophilic molecules. This method also need specialized equipment (Azmir et al., 2013; CastroLopez et al., 2017; Dominguez-Rodriguez et al., 2017).

\subsection{Advanced Extraction Techniques}

These techniques are generally used to assist the solvent extraction by disrupting the plant materials to increase the yield of phenolics.

\section{Microwave assisted extraction}

With controlled pressure and temperature, usage of microwave helps to reduce the time needed for extraction and also decrease the amount of solvent to be used. By this way, it increases the yield of phenolic compounds obtained from plant material (Azmir et al., 2013; CastroLopez et al., 2017; Dominguez-Rodriguez et al., 2017).

\section{Ultrasonic extraction}

The process depends on the production of local pressures by making bubbles with ultrasonication. When bubbles exploit, they disrupt the plant cell and cell wall. Therefore, it increases the amount of released phenolic compound (Azmir et al., 2013; Castro-Lopez et al., 2017; DominguezRodriguez et al., 2017).

Pulsed electric field extraction

It is based on the same principle with electroporation, which give electro-shock to the plant materials. Thus it makes the cell soft and influences cell infrastructure, which resulted in higher yield by increasing the release of phytochemicals (Azmir et al., 2013; Castro-Lopez et al., 2017; Dominguez-Rodriguez et al., 2017).

\section{Enzyme assisted extraction}

This is the most specialized method that uses special enzymes especially for degradation of cell wall. Hence, it causes the release of cell wall bound phytochemicals and reduces the amount of solvent usage (Azmir et al., 2013; Castro-Lopez et al., 2017; Dominguez-Rodriguez et al., 2017). 


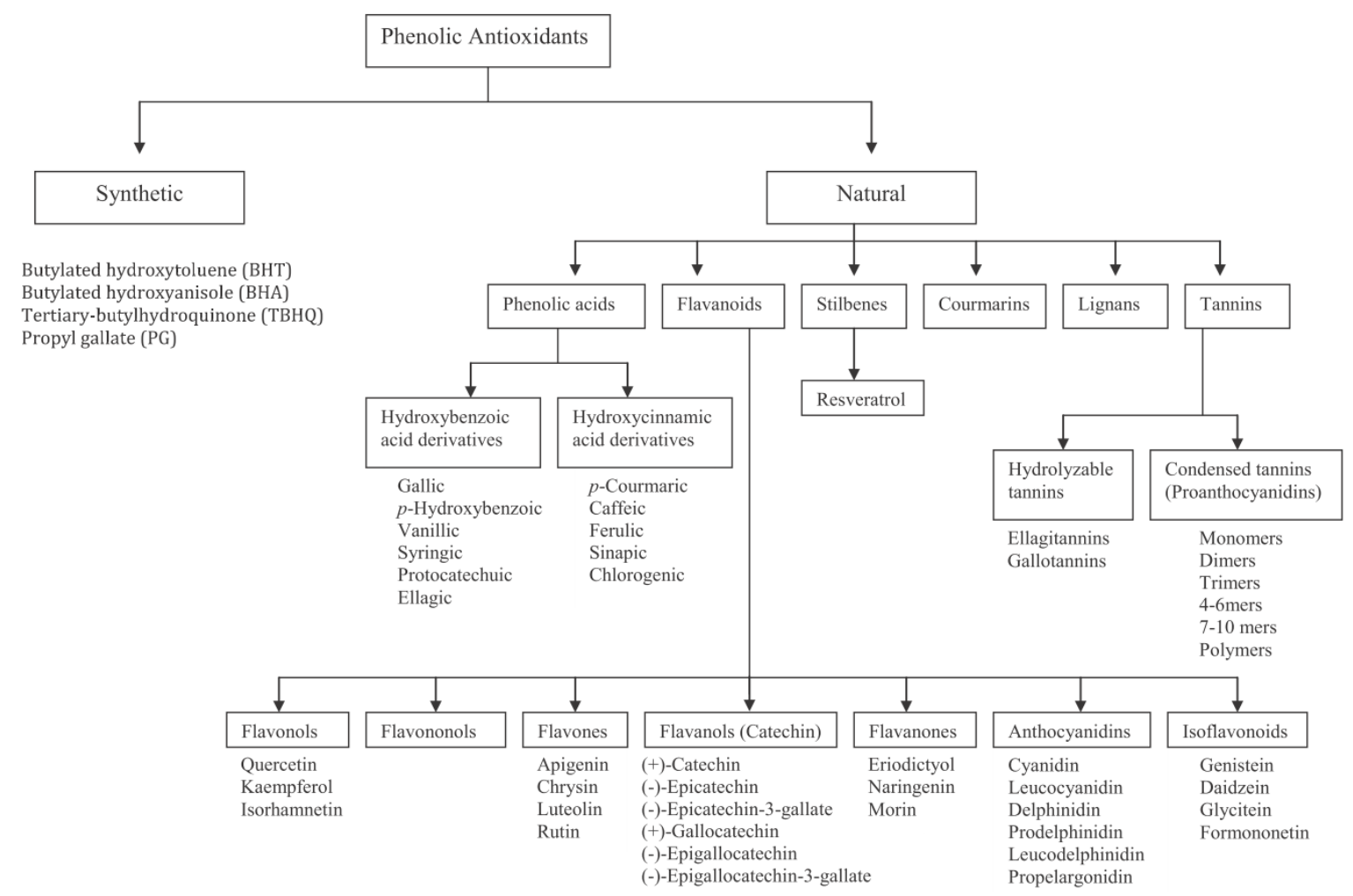

Figure 2. Classification of phenolic antioxidants (Shahidi and Ambigaipalan, 2015)

\section{Analysis of phenolic compounds}

Analysis on phenolics is performed in three main framework: I) Determination of total phenolic content, II) Determination of antioxidant capacity and III) Optional analysis which can include antimicrobial, anticancer, antiinflammatory and cytotoxic effects etc.

Although reducing sugars and amino acids (especially ascorbic acid) can react with the Folin-Ciocalteu reagent, the Folin- Ciocalteu assay is widely used and accepted method for total phenolic content determination (Silva and Sirasa, 2018). Besides that, HPLC coupled with the reverse phase $\mathrm{C} 18$ is also preferred technique for phenolic content determination and its combination with mass spectroscopy provides chemical analysis of the phytochemicals as both in qualitative and quantitative characterization (AcostaEstrada et al., 2014; Dominguez-Rodriguez et al., 2017).

On the other hand, for the antioxidant capacity measurement, there are more than one equivalent methods. Conventional methods includes DPPH (1, 1diphenyl-2-picrylhydrazyl) scavenging activity, ferric reducing/antioxidant power (FRAP), hydroxyl radicalscavenging capacity (HRSCA), Trolox equivalent capacity (TEAC), oxygen radical absorbance capacity (ORAC), cupric ion reducing antioxidant capacity (CUPRAC) assays (Dai and Mumper, 2010; Oroian and Escriche, 2015; Silva and Sirasa, 2018). Although all these five methods are cheap, fast and easy to handle, DPPH and FRAP assays are the most cited and widely used assays for antioxidant capacity measurement. Besides these methods, cyclic voltammetry (especially for beverages), biosensors, chemiluminescent assay, and electron spin resonance spectroscopy are the other methods used for antioxidant capacity determination (Oroian and Escriche, 2015). Although the latter ones are expensive, they are more sensitive than classic methods. It should be noted that all the methods by itself are enough to evaluate the antioxidant effect. Whereas, it should be considered to use more than one method for the precise assessment of to the antioxidant capacity and noted that each analysis has its own standard method.

\section{Conclusion}

Phytochemical composition of plants can vary depending on the situation that plant experiences at that moment. As a living thing, plants together with their biological conditions react to environmental stimuli. In other words, each factor either autochthonous (biotic) or resulted from environment (abiotic) may cause metabolic changes in the plant. Therefore, development stages of the plant, climatic changes, interaction with microorganisms (either symbiotic or pathogen), injuries, and etc. can affect the metabolic composition of a plant. Moreover, since these metabolites have different functions and differ in structure, their location and behavior against a solvent should be distinctive. Thus, pretreatment of plant materials and usage of more than one method based on features of molecules of interest for extraction could help the revealing of plants full potential. Besides, investigation of new methods is required.

\section{References}

Acosta-Estrada BA, Gutiérrez-Uribe JA, Serna-Saldívar SO (2014). Bound Phenolics In Foods, A Review. Food Chemistry 152:46-55. 
Azmir J, Zaidul ISM, Rahman MM, Sharif KM, Mohamed A, Sahena F, Jahurul MHA, Ghafoor K, Norulaini NAN, Omar AKM (2013). Techniques for Extraction of Bioactive Compounds from Plant Materials: A Review. Journal of Food Engineering 117: 426-436.

Bahiense JB, Marques FM, Figueira MM, Vargas TS, Kondratyuk TP, Endringer DC, Scherer R, Fronza M (2017). Potential Anti-Inflammatory, Antioxidant and Antimicrobial Activities of Sambucus Australis. Pharmaceutical Biology 55:991-997.

Barba FJ, Zhu Z, Koubaa M, Sant'Ana AS, Orlien V (2016). Green Alternative Methods for the Extraction of Antioxidant Bioactive Compounds from Winery Wastes and By-Products: A Review. Trends in Food Science \& Technology 49:96e109.

Bhat FM, Riar CS (2017). Extraction, Identification and Assessment of Antioxidative Compounds of Bran Extracts of Traditional Rice Cultivars: An Analytical Approach. Food Chemistry 237:264-274.

Bhattacharya A, Sood P, Citovsky V (2010). The Roles of Plant Phenolics in Defence and Communication during Agrobacterium and Rhizobium Infection. Molecular Plant Pathology 11(5):705-719.

Burgos-Edwards A, Jiménez-Aspee F, Thomas-Valdés S, Schmeda-Hirschmann G, Theoduloz C (2017). Qualitative and Quantitative Changes in Polyphenol Composition and Bioactivity of Ribes Magellanicum and R. Punctatum after In Vitro Gastrointestinal Digestion. Food Chemistry 237:1073-1082.

Castro-López C, Ventura-Sobrevilla JM, González-Hernández MD, Rojas R, Ascacio-Valdés JA, Aguilar CN, Martínez-Ávila GCG (2017). Impact of Extraction Techniques on Antioxidant Capacities and Phytochemical Composition of PolyphenolRich Extracts. Food Chemistry 237:1139-1148.

Celep E, İnan Y, Akyüz S, Yesilada E (2017). The Bioaccessible Phenolic Profile and Antioxidant Potential of Hypericum Perfoliatum L. After Simulated Human Digestion Industrial Crops \& Products 109:717-723.

Cheynier V (2012). Phenolic Compounds: From Plants to Foods. Phytochem Rev 11:153-177.

Cheynier V, Comte G, Davies KM, Lattanzio V, Martens S (2013). Plant Phenolics: Recent Advances on Their Biosynthesis, Genetics, and Ecophysiology. Plant Physiology and Biochemistry 72:1e20.

Dai J, Mumper RJ (2010). Plant Phenolics: Extraction, Analysis and Their Antioxidant and Anticancer Properties. Molecules 15:7313-7352.

Demir N, Yildiz O, Alpaslan M, Hayaloglu AA (2014). Evaluation of Volatiles, Phenolic Compounds and Antioxidant Activities of Rose Hip (Rosa L.) Fruits in Turkey. LWT - Food Science and Technology 57:126e133.

Domínguez-Rodríguez G, Marina ML, Plaza M (2017). Strategies for the Extraction and Analysis of Non-Extractable Polyphenols from Plants. Journal of Chromatography A, 1514:1-15.

Elmastas M, Demir A, Genç N, Dölek Ü, Günes M (2017). Changes In flavonoid And Phenolic Acid Contents in Some Rosa Species during Ripening. Food Chemistry 235:154-159.

Ferhat M, Erol E, Beladjila KA, Çetintaş Y, Duru ME, Öztürk M, Kabouche A, Kabouche Z (2017). Antioxidant, Anticholinesterase and Antibacterial Activities of Stachys Guyoniana and Mentha Aquatic. Pharmaceutical Biology, 55:324329.

Galanakis CM (2012). Recovery of high added-value components from food wastes: Conventional, emerging technologies and commercialized applications. Trends in Food Science \& Technology 26(2):68-87.

Galindo A, Calín-Sánchez A, Griñán I, Rodríguez P, Cruz ZN, Girón IF, Corell M, Martínez-Font R, Moriana A, CarbonellBarrachina AA, Torrecillas A, Hernández F (2017). Water Stress At The End Of The Pomegranate Fruit Ripening Stage Produces Earlier Harvest And Improves Fruit Quality. Scientia Horticulturae 226:68-74.

Iseri OD, Körpe DA, Yurtcu E, Sahin FI, Haberal M (2011). Copper-induced oxidative damage, antioxidant response and genotoxicity in Lycopersicum esculentum Mill. and Cucumis sativus L. Plant Cell Reports, 30(9):1713-21.

Kada S, Bouriche H, Senator A, Demirtaş I, Özen T, Toptanci BÇ, Kızıl G, Kızıl M (2017). Protective Activity of Hertia Cheirifolia Extracts against DNA Damage, Lipid Peroxidation and Protein Oxidation. Pharmaceutical Biology, 55:330-337.

Kolakul P, Sripanidkulchai B (2017). Phytochemicals and Anti-Aging Potentials of the Extracts from Lagerstroemia Speciosa and Lagerstroemia floribunda. Industrial Crops \& Products 109:707-716.

Li Y, Bao T, Chen W (2018). Comparison of the Protective Effect of Black And White Mulberry against Ethyl CarbamateInduced Cytotoxicity and Oxidative Damage. Food Chemistry 243:65-73.

Liu B, Zhao S, Tan F, Zhao H, Wang D, Si H, Chen Q (2017). Changes in ROS Production and Antioxidant Capacity during Tuber Sprouting In Potato. Food Chemistry 237:205-213.

Mabeku LBK, Bille BE, Tchouangueu TF, Nguepi E, Leundji H (2017). Treatment of Helicobacter Pylori Infected Mice with Bryophyllum Pinnatum, A Medicinal Plant with Antioxidant and Antimicrobial Properties, Reduces Bacterial Load. Pharmaceutical Biology, 55(1):603-610.

Majdoub N, El-Guendouz S, Rezgui M, Carlier J, Costa C, Kaab LBB, Miguel MG (2017). Growth, Photosynthetic Pigments, Phenolic Content and Biological Activities of Foeniculum Vulgare Mill., Anethum Graveolens L. And Pimpinella Anisum L. (Apiaceae) In Response to Zinc. Industrial Crops \& Products 109:627-636.

Marques P, Marto J, Gonçalves LM, Pacheco R, Fitas M, Pinto P, Serralheiro MLM, Ribeiro Cynara H (2017). Scolymus L.: A Promising Mediterranean Extract for Topical Anti-Aging Prevention. Industrial Crops \& Products 109:699-706.

Martini S, Conte A, Tagliazucchi D (2017). Phenolic Compounds Profile and Antioxidant Properties of Six Sweet Cherry (Prunus Avium) Cultivars. Food Research International 97:15-26. 
Mirto A, Iannuzzi F, Carillo P, Ciarmiello LF, Woodrow P, Fuggi A (2018). Metabolic Characterization and Antioxidant Activity in Sweet Cherry (Prunus Avium L.) Campania Accessions Metabolic Characterization of Sweet Cherry Accessions. Food Chemistry 240:559-566.

Nađpala JD, Lesjak MM, Mrkonjić ZO, Majkić TM, Četojević-Simin DD, Mimica-Dukić NM, Beara IN (2018). Phytochemical Composition and In Vitro Functional Properties of Three Wild Rose Hips and Their Traditional Preserves. Food Chemistry 241:290-300.

Nunes R, Pasko P, Tyszka-Czochara M, Szewczyk A, Szlosarczyk M, Carvalho IS (2017). Antibacterial, Antioxidant and AntiProliferative Properties and Zinc Content of Five South Portugal Herbs. Pharmaceutical Biology, 55:114-123.

Ojeda-Amador RM, Fregapane G, Salvador MD (2018). Composition and Properties of Virgin Pistachio Oils and Their ByProducts from Different Cultivars. Food Chemistry 240:123-130.

Oke-Altuntas F, Ipekcioglu S, Yaglioglu AS, Behcet L, Demirtas I (2017). Phytochemical Analysis, Antiproliferative and Antioxidant Activities of Chrozophora Tinctoria: A Natural Dye Plant. Pharmaceutical Biology, 55:966-973.

Oroian M, Escriche I (2015). Antioxidants: Characterization, Natural Sources, Extraction and Analysis. Food Research International 74:10-36.

Petropoulos S, Fernandes A, Karkanis A, Ntatsi G, Barros L, Ferreira ICFR (2017). Successive Harvesting Affects Yield, Chemical Composition And Antioxidant Activity Of Cichorium Spinosum L. Food Chemistry 237:83-90.

Petropoulos SA, Fernandes A, Vasileios A, Ntatsi G, Barros L, Ferreira ICFR (2018). Chemical Composition and Antioxidant Activity of Cichorium Spinosum L. Leaves In Relation To Developmental Stage. Food Chemistry 239:946-952.

Pezeshkpour V, Khosravani SA, Ghaedi M, Dashtian K, Zareb F, Sharifi A, Jannesar R, Zoladl M (2018). Ultrasound Assisted Extraction Of Phenolic Acids From Broccoli Vegetable And Using Sonochemistry For Preparation Of MOF-5 Nanocubes: Comparative Study Based On Micro-Dilution Broth And Plate Count Method For Synergism Antibacterial Effect. Ultrasonics - Sonochemistry 40:1031-1038.

Pisoschi AM, Pop A (2015). The Role of Antioxidants in the Chemistry of Oxidative Stress: A Review. European Journal of Medicinal Chemistry 97:55e74.

Sadi G, Sadi Ö (2010). Antioxidants and Regulation of Antioxidant Enzymes by Cellular Redox Status. Turkish Journal and Scientific Reviews 3(2): 95-107.

Shahidi F, Ambigaipalan P (2015). Phenolics and Polyphenolics in Foods, Beverages and Spices: Antioxidant Activity and Health Effects -A Review. Journal of Functional Foods 18:820-897.

Shahidi F, Zhong Y (2015). Measurement of Antioxidant Activity. Journal of Functional Foods 18:757-781.

Siddiqui MA, JMehta N, Khan IA (2003). Paracelsus: the Hippocrates of the Renaissance. Journal of Medical Biography 11: 78 80 .

Silva KDRR, Sirasa MSF (2018). Antioxidant Properties of Selected Fruit Cultivars Grown In Sri Lanka Food. Chemistry 238:203-208.

Staal FJT, Pike-Overzet K, Ng YY, van Dongen JJM (2008). Sola Dosis Facit Venenum. Leukemia in Gene Therapy Trials: A Question of Vectors, Inserts and Dosage. Leukemia 22:1849-1852.

Sutay Kocabaş D, Tur E, Kocabas A (2015). Phytochemical Analysis of Some Native Apple Varieties and Valorization of Apple Tree Leaves for Xylanase Production. The Journal of FOOD 40(5):1-8.

Tupec M, Hýsková V, Bělonožníková K, Hraníček J, Červený V, Ryšlavá H (2017). Characterization of Some Potential Medicinal Plants from Central Europe by Their Antioxidant Capacity and the Presence of Metal Elements. Food Bioscience 20:43-50.

Wang S, Zhu F (2017). Chemical Composition and Biological Activity of Staghorn Sumac (Rhus Typhina). Food Chemistry 237:431-443.

Cite this article: Kocabaş A (2017). Ease of Phytochemical Extraction and Analysis from Plants? Anatolian Journal of Botany 1(2): 26-31. 